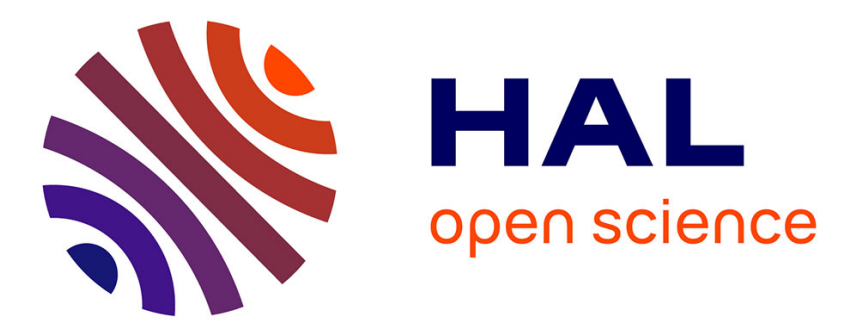

\title{
Moss caulking of boats in upper French Rhône and Saône (Eastern France) from the 3rd to the 20th century and the use of Neckera crispa Hedwig
}

Arne Saatkamp, Marc Guyon, Marc Philippe

\section{- To cite this version:}

Arne Saatkamp, Marc Guyon, Marc Philippe. Moss caulking of boats in upper French Rhône and Saône (Eastern France) from the 3rd to the 20th century and the use of Neckera crispa Hedwig. Vegetation History and Archaeobotany, 2011, 17, pp.293-304. 10.1007/s00334-011-0301-7 . hal01533479

\author{
HAL Id: hal-01533479 \\ https://hal.science/hal-01533479
}

Submitted on 24 Jun 2018

HAL is a multi-disciplinary open access archive for the deposit and dissemination of scientific research documents, whether they are published or not. The documents may come from teaching and research institutions in France or abroad, or from public or private research centers.
L'archive ouverte pluridisciplinaire HAL, est destinée au dépôt et à la diffusion de documents scientifiques de niveau recherche, publiés ou non, émanant des établissements d'enseignement et de recherche français ou étrangers, des laboratoires publics ou privés. 


\title{
Moss caulking of boats in upper French Rhône and Saône (Eastern France) from the 3rd to the 20th century and the use of Neckera crispa Hedwig
}

\author{
Arne Saatkamp - Marc Guyon - Marc Philippe
}

\begin{abstract}
The use of moss material to make boats watertight (caulking) has been a widespread practice in Europe, with records dating back to the Bronze Age. In this article we report the bryophyte assemblages from fifteen boats, which have been conserved as wrecks in the rivers of Upper Rhône and Saône near Lyons, France. The assemblages vary according to their composition, with Neckera crispa Hedwig being one of the dominant species overall. Following ancient technical descriptions we performed experimental collections from bark and rocks in the Jura Mountains. Comparing these to the archaeological records revealed that most of the mosses were probably of bark origin and were collected in base rich areas. Our data is discussed in the context of archaeological caulking in Western Europe. While in much of Europe $N$. crispa strongly decreased as a caulking material from the 14th
\end{abstract}

\author{
A. Saatkamp (ه) \\ Institut Méditerranéen d'Écologie et de Paléoécologie IMEP \\ IRD UMR CNRS 6116, Université d'Aix Marseille III, FST \\ Saint Jérôme Case 462, 13397 Marseille Cedex 20, France \\ e mail: arnesaatkamp@gmx.de \\ M. Guyon \\ INRAP, Région Rhône Alpes Auvergne, Centre \\ Archéologique Régional de Bron, 12, rue Louis Maggiorini, \\ 69500 Bron, France \\ e mail: marc.guyon@inrap.fr \\ M. Philippe \\ UMR5125 (PEPS) du CNRS, Université Lyon 1, Campus de la \\ Doua, Darwin A, 69622 Villeurbanne Cedex, France \\ e mail: philippe@univ lyon1.fr
}

century onwards, it remained much used in our study area. This is probably due to the persistence of suitable forests in the Jura mountains.

Keywords Bryophytes - Boat wreck - Epiphytes · Moss macro-remains

\section{Introduction}

Caulking is essential to make boats watertight. Traditionally, the gaps between planks of wooden boats or cracks in monoxylous boats were sealed by forcing organic material into them. During this process, called "caulking", various materials were used, either of plant (flax, moss, hemp, reeds etc.) or animal (wool, hairs etc.) origin, sometimes combined with various viscous substances (resin, tar etc.).

In Northwestern Europe, moss caulking dominated fluvial boatbuilding from the Bronze Age to the mid-19th century (Dickson 1973; Arnold 1975; Knörzer 1999; Wright 1994; Rieth 1996; Cappers et al. 2000; Clark 2004). Nail joint and moss caulking are major specifics of Celtic boatbuilding (Arnold 2001), although within areas of Celtic influence boatbuilding techniques otherwise differed regionally (Arnold 1977; Bonnamour 2000). In non-Mediterranean Western Europe a caulking technique where moss was rolled into cords predominated. One or several moss-cords were forced into a seam to caulk it with the help of a wooden wedge and a caulking mallet. This moss layer sometimes overlaid a rope, which was sometimes plaited from Polytrichum species. The caulk was then covered with a split stick, which was retained with curved nails (Arnold 1977; Cappers et al. 2000).

Several studies have analyzed the moss content of archaeological caulking material in Western Europe 
(Ochsner 1975; Arnold 1975, 1977, 1992; Rösch 1988; Diot 1991; Knörzer 1999; Cappers et al. 2000; Frahm and Wiethold 2004; Heiss and Reitmaier 2005; Heras-Pérez et al. 2009). In most cases, local supply dominates. However, at least until the 14th century, three species dominated the caulking material: Neckera crispa, Thuidium tamariscinum and Loeskobryum brevirostre. The first one is particularly common. Consequently, this species was used for experimental archaeology reconstructions of wooden boats (Arnold 2001). From the 15th century on, the use of these three species declined in several regions of Europe, particularly in the case of $N$. crispa. These species were replaced by Sphagnum and wetland pleurocarpous mosses, which became more frequently used. This replacement might be either due to changes in the local bryoflora (possibly bound to local environmental changes) or to a change in the technical choices of boatbuilders (Cappers et al. 2000).

Despite this general trend, we observed that $N$. crispa remained the dominant material for moss caulking along the Saône and Upper French Rhône rivers, up until this technique was abandoned shortly after the Second World War. Even after 1900, while moss-caulking was replaced by other techniques using hemp or flax in other regions, $N$. crispa, locally known as "box-moss", was still favoured by many boat builders, who valued its durability and excellent properties for making boats watertight (Bonnamour 1981; Blanc 1986). Here, we analyse caulking material of 15 boat remains, dating to the period between the $3 \mathrm{rd}$ and the 20th century, to address:

(1) How the composition of moss-caulking evolved through this period and how it compares with other European records
(2) Whether N. crispa was specifically recognised and collected for moss-caulking

(3) Whether the general decrease in the use of $N$. crispa for caulking was rather due to environmental changes or change in production procedures.

Finally, we completed our approach by interviewing witnesses and analysing experimental moss collections.

\section{Materials and methods}

Analysis of moss caulking material

We investigated macro-remain samples of mosses from 15 boats. Ten records were studied in previous unpublished reports, and five are newly studied here. All 15 boats were studied using the same methods. They were all found in the Saône or the Rhône rivers upstream of Lyons (Fig. 1). For every wreck several samples were taken, from the bow to the stern, paying attention to the collection of the whole seal. The samples, which had a size of $410 \mathrm{~cm}^{3}$ each, contained only bryophytes and some fragments of vascular plants, but lacked remains of resin or tar as sometimes observed elsewhere (Heras-Pérez et al. 2009). We kept the samples humid until they were analysed. In some cases we were not able to process samples directly; we then froze samples to ensure optimal conservation. We took one to three subsamples of $1 \mathrm{~cm}^{3}$ each per sample, depending on preservation of the material. These subsamples were then sorted under a stereomicroscope (Wild M3Z). Subsamples usually contained about one hundred moss leafy stems. Determination was done under a microscope (Zeiss), on the
Fig. 1 Map of the study area in the Upper Rhône and Saône region, France

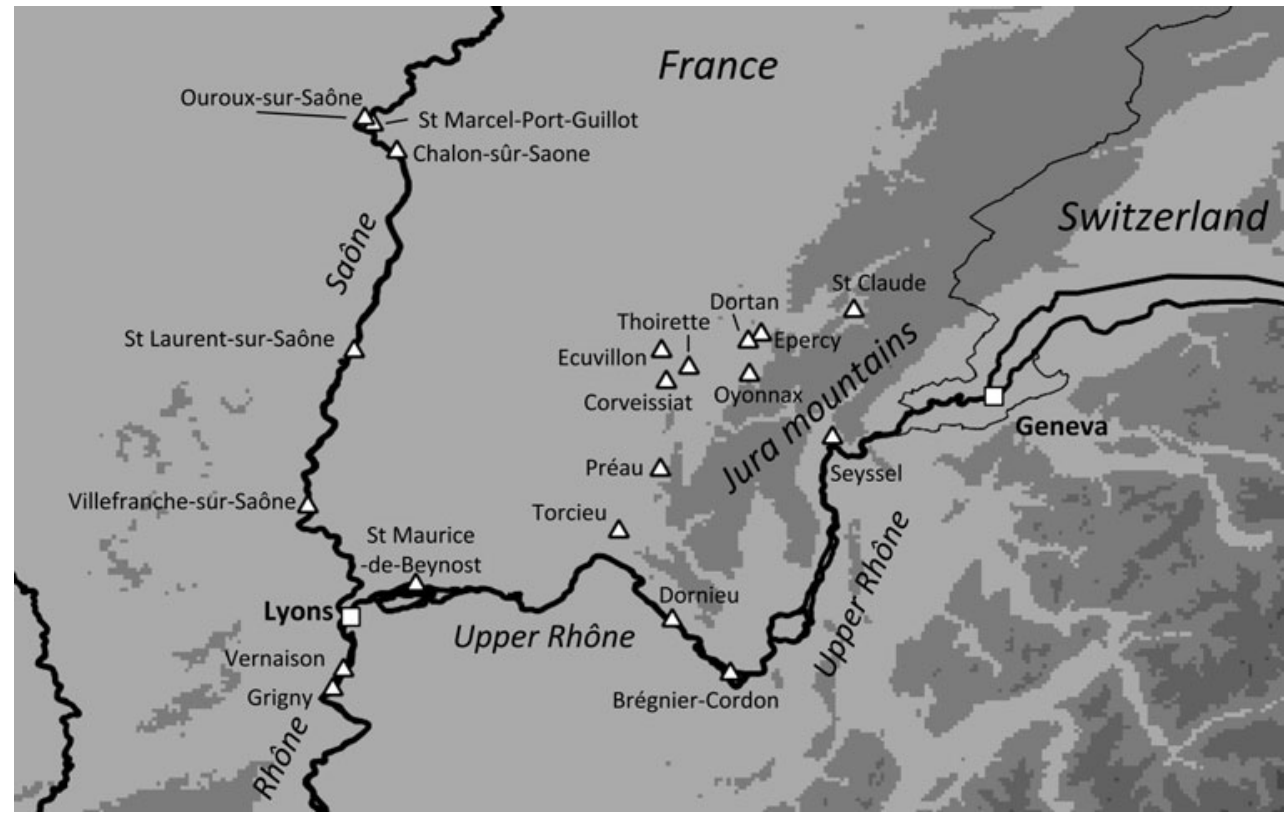


basis of microscopic features such as leaf areolation, papillae, nerve, leaf shape and size, using Frey et al. (2006) and a reference collection of securely identified bryophytes. The nomenclature follows Hill et al. (2006). For counting purposes only leafy shoots were counted and we did not include isolated leaves and fragments. Since isolated shoots of Homalothecium sericeum and H. lutescens are near to indistinguishable, we united them into one morpho-species recorded in Table 1 under H. sericeum.

\section{Literature accounts of moss usage for caulking}

We browsed the literature to obtain accounts of moss collections for caulking. Moss caulking was not only used for boats, but also for wooden houses, bridge bases, mines and various wooden board constructions. We therefore focused on moss collections that were done specifically for boatbuilding. Two persons with firsthand experience of moss caulking of boats were interviewed: Louis-René Catcel from Lhuis, who collected caulking moss in his childhood and moss caulked boats until about 1960 and Odette Josserand, from Villefranche-sur-Saône, whose father was a boat builder and performed moss caulking until 1960.

There are accounts from the 19th century for the Forez plain, west of Lyons, stating that women used to take advantage of pilgrimages to well-forested sanctuaries to collect caulking moss (Rochigneux 1891). At that time, moss was a scarce resource since it was used for various purposes, such as sleeping mats (Hypnum), insulating material and caulking

\section{Experimental moss collections}

It became clear from various literature accounts and our preliminary results that the Jura Mountains were a major source of caulking moss, for boats in the Lyons area and during the 20th century at least. Some accounts also insisted that moss had to be "clean" (i.e. free from other plant debris or soil; Bonnamour 1981), in long threads and elastic (Grave 1857). We also supposed that collectors tried to optimize their time and thus collected in areas where large quantities of suitable moss was available. Large quantities of clean moss in long curtains can usually be found on vertical surfaces like cliffs and tree-trunks, and several accounts explicitly reported collections from the bases of trees (Janod 1983).

Swamps and other aquatic habitats are suitable for the collection of large amounts of moss fitting the technical features described above, for example among the genera Calliergonella, Cinclidotus, Cratoneuron and notably Sphagnum; genera that were (and are still) used for caulking in other regions (Diot 1991; Cappers et al. 2000; Frahm and Wiethold 2004; Bailly personal communication; Unterstock personal communication). However, our samples presented in Table 1 do not feature any species of aquatic or swamp habitat, therefore these habitats were not visited in experimental moss collections.

We identified twenty-six sites in the Jura Mountains (see caption of Table 2 and Fig. 1) with a large amount of clean moss in long curtains. All sites were in forested areas, and the experimental gatherings took place at least 2 days after the last rain and outside of drought periods. At each place, we collected about one kilogram in a plastic bag. We weighed these samples on the same day (fresh weight). We then sorted species, and eventually calculated weight percentages for each species.

Ellenberg indicator values and multivariate analysis

Ellenberg et al. (1992) provided a system of indicator values giving the ordinal position of a species on gradients of light, temperature, moisture and substrate bases content for the mosses in the central European flora. Indicator values are numbers from 1 to 9 for low to high values along each gradient. Using mean values of these indicator values for plant assemblages is a very sensible way to assess relative position and changes in habitat conditions (Diekmann 2003). We did this by calculating the mean values for the light, temperature, moisture and base content for archaeological and experimental records. We then tabulated these values in Fig. 1 to compare archaeological and experimental assemblages relative to these factors. We prefer the use of the Ellenberg system to the system of Dierssen (2001) since data are readily available in tabulated form, and the Ellenberg indicator system is now becoming widely used, making our analysis comparable to other studies.

Moreover, we analysed similarities in species composition between archaeological and experimental records using a correspondence analysis (Legendre and Legendre 1998). Correspondence analysis was applied to a table using both data sets combined, from which we deleted species occurring only once and records containing only one species.

\section{Results}

Moss caulking analysis

The results of the analysis of moss macro-remains from boat wrecks in the Lyons area are given in Table 1. These reflect quite contrasting results in composition. They are analysed in more detail in Figs. 2 and 3, giving details on 


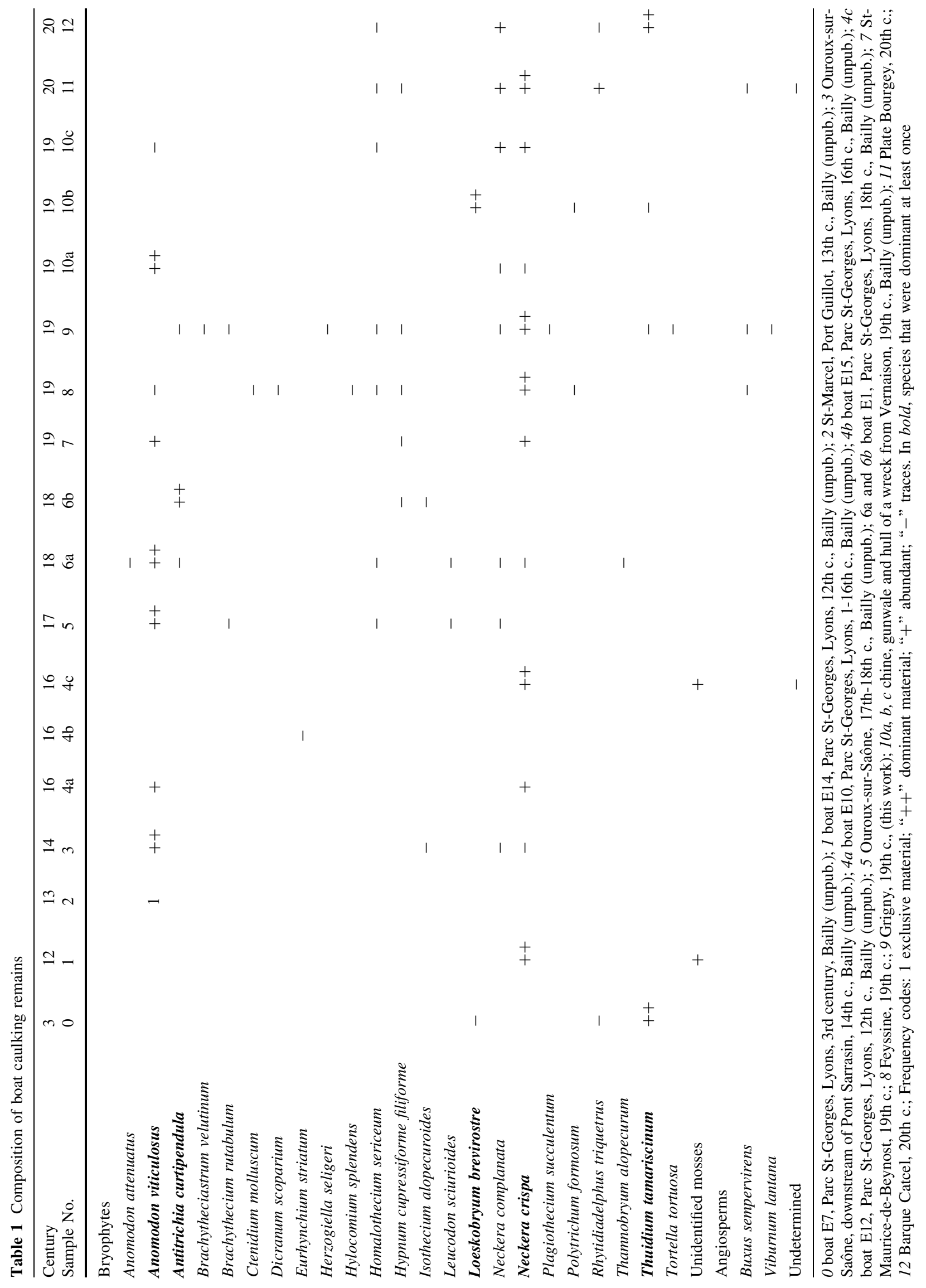




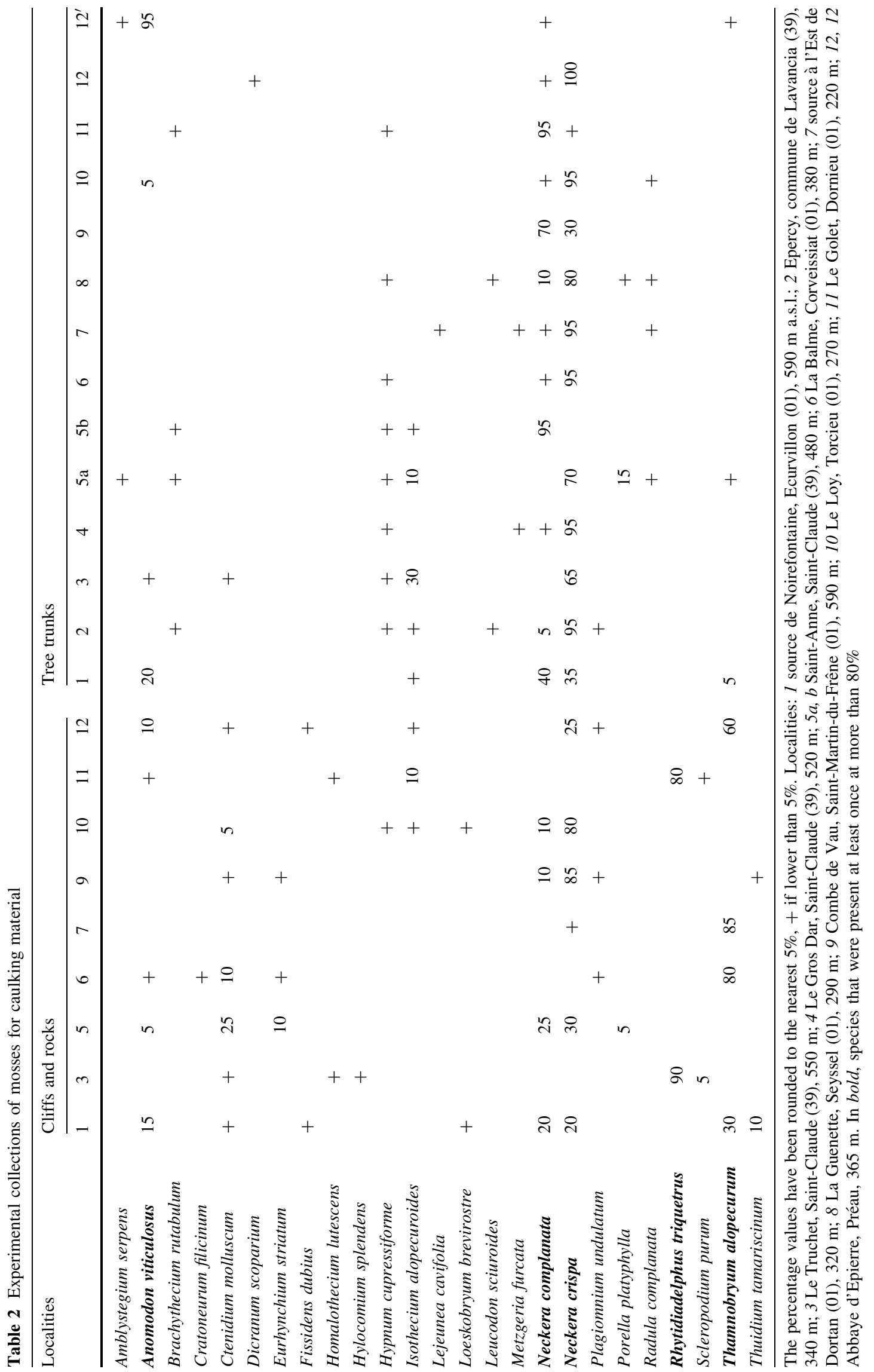


Fig. 2 Position on gradients of light (a), temperature (b), moisture (c) and bases content (d) of the archaeological records of mosses from boat caulking material in the Lyons area arranged according to date; experimental records arranged according to rock or bark substrate
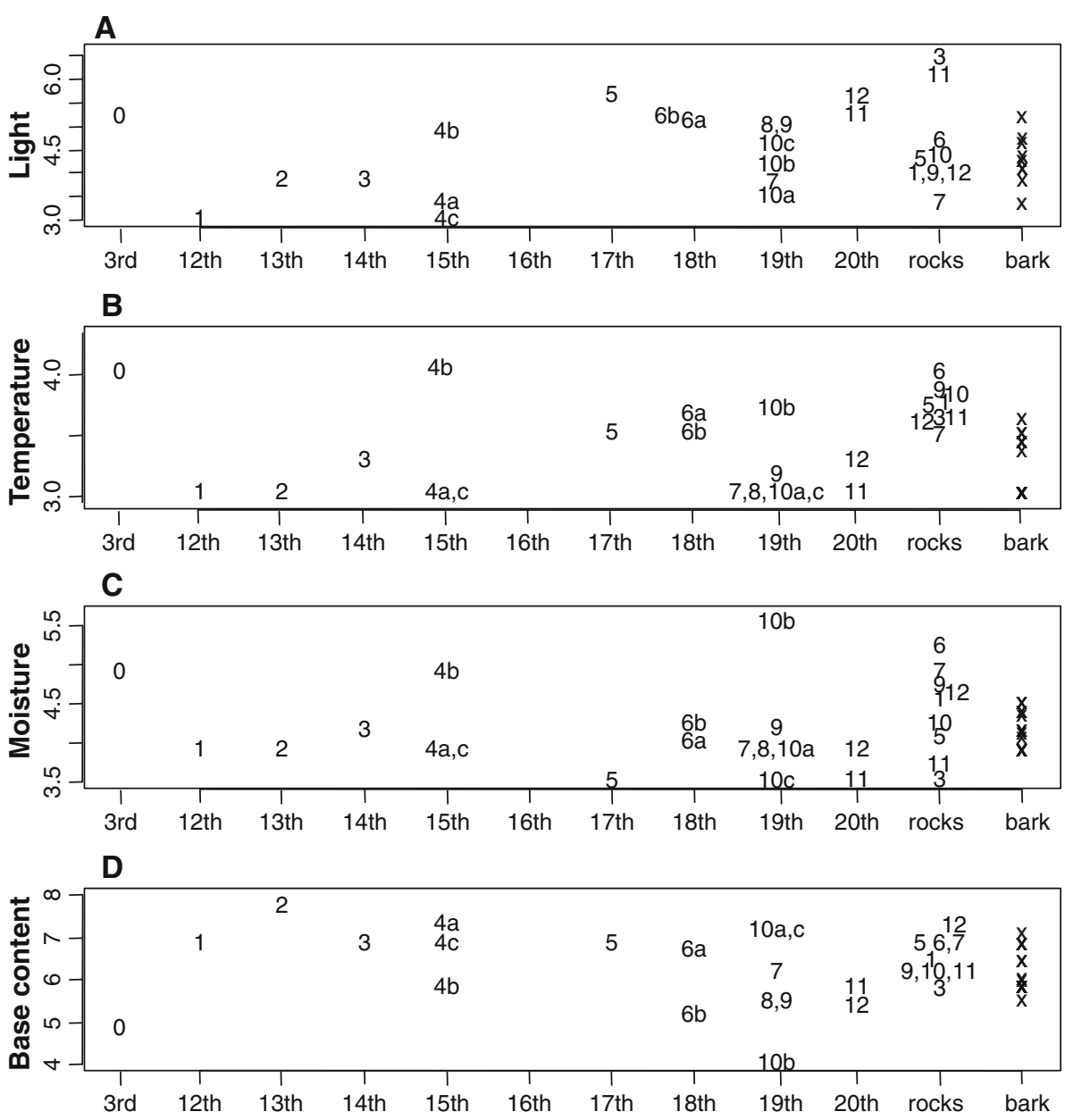

the similarities in terms of species composition (Fig. 3) and the position of these assemblages on gradients of light, temperature, moisture and substrate base content (Fig. 2).

\section{Experimental moss collections}

The species of Table 1 can be encountered almost everywhere between the Saône and Rhône Rivers north of Lyons (Philippe 2006). Nevertheless, they are clearly much more abundant today at low altitude (up to $600700 \mathrm{~m}$ a.s.l.) in the numerous steep valleys cut through limestone hills of the Jura Mountains and Northern Savoie. This fits with the observations of Argant et al. (2000), who have shown that this area was probably the source area for 19th century moss caulking (wreck no. 7 in Table 1), and with the results of Bailly (in Rieth 2010) who concluded that Jura probably remained the dominant source area for caulking moss upstream of Lyons throughout historical times. Anomodon viticulosus and N. crispa are particularly abundant in this area and form thick curtains on trunks and cliffs; they are also highly dominant species in caulking material from archaeological sites (Table 1). The species composition of archaeological accounts of moss caulking in Table 1 did not at all resemble a gathering made in a forest on acidic ground, like those of the Haut-Beaujolais. Therefore we decided to do our experimental moss collections in the Jura Mountains.

Experimental collection of caulking moss material had already been performed in the Swiss Jura Mountains by Arnold (2001), specifically focussing on N. crispa. However, these gatherings were limited to cliffs and rocky screes and only a part of the stands have been collected. In his work, four people collected $200 \mathrm{~kg}$ of moss within 5 days. In the French Jura, Pétrequin et al. (1991) collected moss for the caulking of log-houses around Chalain (Jura department). Five hours of work were needed to collect about $60 \mathrm{~kg}$ of moss.

At several places in the Département Ain, we noticed large and dense carpets of large pleurocarps (Rhytidiadelphus triquetrus, R. loreus, Hylocomnium splendens, Pleurozium schreberi, Scleropodium purum) which are apparently suitable as caulking material. However, the proportion of these species in the moss-assemblages of archaeological caulking material as studied here (Table 1) is not significant (these species have been, however, very much used in other regions of Western Europe; Grave 

archaeological caulking samples (C) and experimental gatherings from bark (T) and rocks (R) as revealed by the two first axes of a correspondence analysis; numbers refer to record numbers in Tables 1 and 2
Fig. 3 Similarities of moss assemblages from

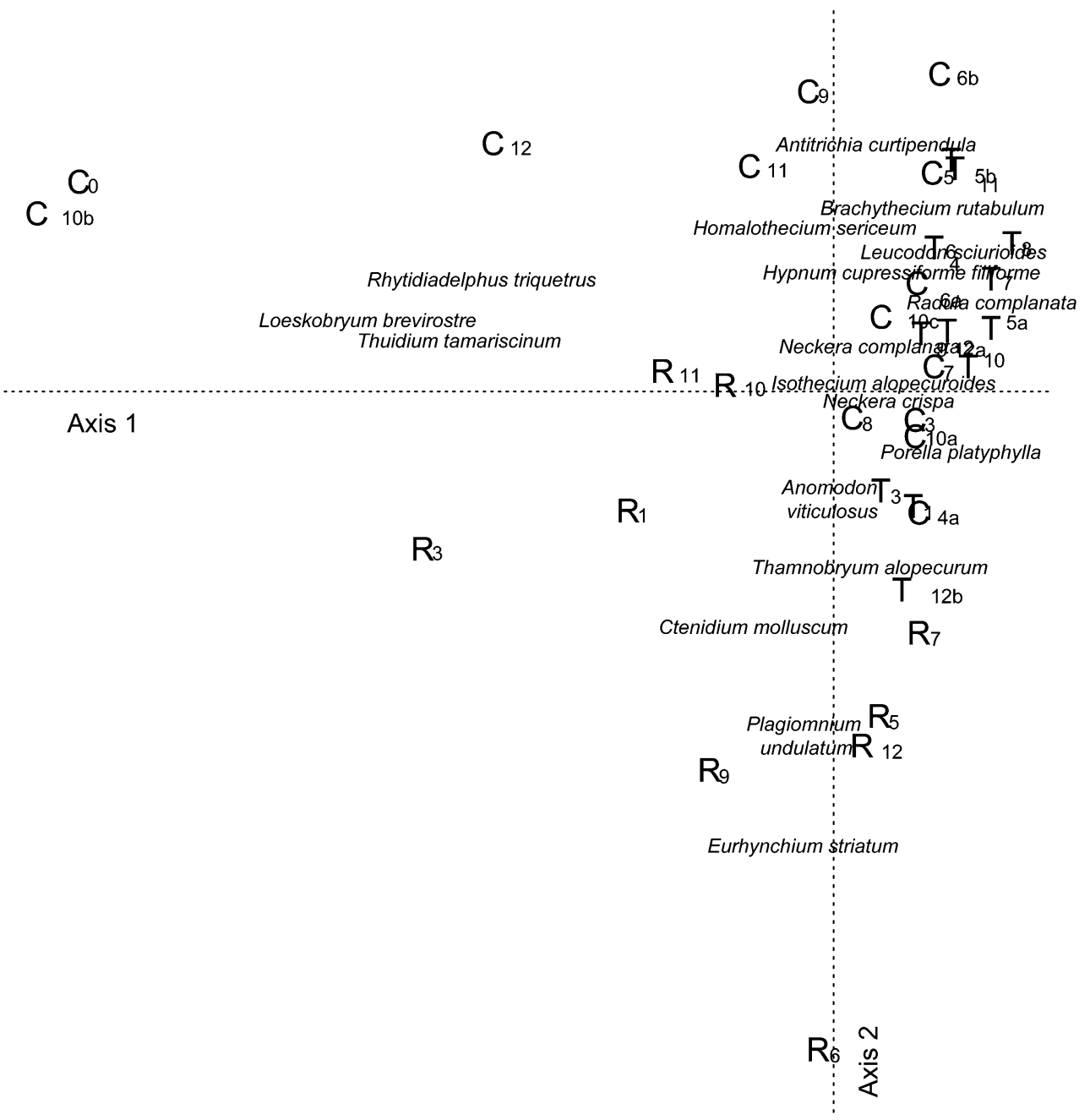

1857; Diot 1991; Cappers et al. 2000; Heiss and Reitmaier 2005; Heras-Pérez et al. 2009). Most of these mosses are not as flexible and tough as N. crispa or A. viticulosus, and their stands are often intermingled with plant debris. On stony ground Ctenidium molluscum often forms large carpets, which again would seem suitable. However, collecting broke these carpets. During preliminary investigations, we also observed that Thamnobryum alopecurum becomes brittle once compressed, although it sometimes builds dense carpets with a web of long stems. These first results were used to select places for experimental collection of caulking material. As stated above we selected areas where large quantities of clean moss in long curtains were encountered on vertical surfaces like cliffs and tree-trunks.

Once such an area was identified, one of the authors collected $1 \mathrm{~kg}$ (fresh weight) of moss, following only the technical criteria given above (no species choice). This usually took $910 \mathrm{~min}$. This time included removal of most twigs and leaves or other plant debris. We soon realised that collecting is much easier between $30 \mathrm{~cm}$ and $1.9 \mathrm{~m}$ above the ground level (experimenter height $1.77 \mathrm{~m}$ ). The most suitable source for collection soon appeared to be the trunks of large Buxus sempervirens trees (with at least a $34 \mathrm{~cm}$ diameter at $1.3 \mathrm{~m}$ above the ground), in forests with permanently high air humidity. In these forests large quantities of almost pure moss can be collected relatively quickly, and moreover moss stands are hanging in long and supple threads, which are easy to compress. Collecting in these contexts usually yields more than $95 \%$ of Neckera (either $N$. crispa or N. complanata), while threads usually reached $30 \mathrm{~cm}$ (one $N$. crispa individual at $60 \mathrm{~cm}$ ). Our trials revealed that the collection of monospecific $N$. crispa cushions is clearly the easiest and quickest way to collect large quantities of a moss suitable for caulking. In one gathering we made in an open forest, Anomodon viticulosus dominated the assemblage.

Comparing archaeological and experimental assemblages of caulking moss

The analysis of similarities presented in Fig. 3 shows that about one half of the archaeological records are very 
similar to experimental material collected from bark. The remaining moss assemblages were quite different from experimental assemblages that were collected from both bark and rock.

The inspection of mean indicator values of base content for the archaeological assemblages shows that the mosses used for caulking correspond to base-rich substrates, most of them clearly at least as base rich as experimental material collected from rocks.

Accounts of moss collecting for caulking

Literature accounts of caulking moss collecting are scarce. Janod (1983) mentions such collections at Lavancia and Rhien (Jura department), along the Bienne River, near to the town of Oyonnax. He quotes Henri Bourbon (born in 1902): "the women of Lavancia d'Epercy did collect the delicate moss which grows at the foot of broad-leafed trees. They prepared bundles with the help of three supple sticks they twisted; it made a kind of basket. It was used by boat builders who caulked with this moss" (our translation).

Bonnamour (1981) gives a photograph of a moss collection party near Thoirette (Department Ain), in the Ain River valley, close to Lavancia, in 1948. Tony Huot, a boat builder in Saint-Laurent-les-Mâcon (Saône River), stands with two of his workers in a rather open and low forest, with bags attached to their belts. Behind them are a rudimentary tent and a moss pile that might be the result of half-a-day's work for three persons. The tent could be a day-shelter nothing indicating a long stay.

Madame Odette Josserand told that until 1950 her father, boat builder in Villefranche, bought moss from someone living in Saint-Jean-le-Vieux (Department Ain). Occasionally, when the boat builder was not too busy and in order to spare money, her father used to go up into the mountainous part of the Beaujolais, near Les Echarmeaux. There, on mossy and shady slopes, moss was raked up from the ground and put into bags. Back home the moss was spread in a barn and allowed to dry, before being re-bagged and stored. Such collections usually only took an afternoon.

According to André Julliard (personal communication) around Brégnier-Cordon (southernmost Jura) caulking moss was collected by women and children and was bartered. Louis-René Catcel confirms this, adding that caulking moss was also sometimes collected by the men. It was collected in nearby woods, mostly in oak forest with an undergrowth of box and high air humidity. Moss cushions on trunks were specially targeted, and knowledge of good collecting spots was passed on.

Visiting the boatyard of A. Schleuniger, boat builder near Chalon, Arnold noticed that its old stock of caulking moss was exclusively composed of $N$. crispa
(Arnold 2001). We noticed the same at Louis-René Catcel's boatyard.

Several moss species known in archaeological caulking were presented simultaneously to Louis-René Catcel: Anomodon viticulosus, Ctenidium molluscum, Eurhynchium striatum, Homalothecium lutescens, Neckera complanata, N. crispa (a stunted form from dry cliffs, and a long form from shaded trunks), Rhytidiadelphus triquetrus, Scleropodium purum and Thamnobryum alopecurum. He immediately indicated the long form of $N$. crispa, as being of "a superior quality" (his wording).

\section{Discussion}

How did the composition of moss caulking evolve through time?

The species composition of moss caulking material presented in Table 1 can be compared to data in the literature. Only Cappers et al. (2000) dealt with a time interval comparable to ours. About $60 \%$ of the species we encountered were also mentioned by Cappers et al. (14 out of 23). However, abundances changed. Of five species which were at least once highly dominant in our work (Antitrichia curtipendula, Anomodon viticulosus, N. crispa, Thuidium tamariscinum and Loeskobryum brevirostre) only the latter three were also found with high percentages by Cappers et al. and this always before the 14th century. In the moss caulking samples studied here it is remarkable that $A$. viticulosus and to an even greater extent $N$. crispa had very high relative abundances. This is similar to what has been reported for the Gallo-Roman boats described in Arnold (2001) from the Swiss Jura foothills. Moreover, Knörzer (1999), observed mainly A. viticulosus while studying moss assemblages in caulking material from the 5 th century в.C. and 1st, 9 th and 13th century A.D. in wrecks from the lower Rhine valley.

It is striking that archaeological records of moss communities are on the most base rich part of the gradient displayed in Fig. 2d. Moreover, nearly all these records closely resemble the experimental records collected from bark in terms of species composition as shown by Fig. 3 . Together, these indicate that bryophyte communities on bark might have been much less acidic in ancient times than at present. This is consistent with the very sensitive reaction of bark bryophytes to air pollution and especially bark acidification that is well documented for central European bryophyte communities (Stapper and FranzenReuter 2010). There are however two notable exception to this, the record 0 from the 3 rd century and record $10 \mathrm{~b}$ from the 19th century came from relatively acidic substrates, but clearly not bark communities. 
Interestingly, only the oldest and the youngest samples studied here were caulked mainly with $T$. tamariscinum. Although this species seems suitable for caulking purposes at first sight because of its long and supple shoots, it mostly grows on the ground, and therefore gatherings of it are often intermingled with twigs and litter. Only one sample in Table 1 is dominated by Antitrichia curtipendula. This species forms long curtains on trunks and branches which are usually stands clean of debris, and thus seem suitable for moss-caulking. However, this species is far less common in the Jura Mountains than N. crispa and Anomodon viticulosus. Moreover, its abundance markedly decreased during the 20th century, probably in relation to its high sensitivity to air-pollution (Frey et al. 2006), although it has probably never been a common species. Another boat had been caulked with Loeskobryum brevirostre, a large pleurocarpous moss growing mostly on calcareous rocks. Although it does not form particularly long shoots, L. brevirostre is usually encountered as large monospecific and clean carpets that are easy to collect and permit rapid gathering of a large quantity of moss.

Several authors noticed that some bryophyte species may have been explicitly selected for caulking. Gilles Bailly (1997) suggested that some caulking material samples from the area studied here seemed to be prepared from selected moss species, while other samples were more diversified. This was also been reported by M.-F. Diot (1991) for south-western France. It is known from the literature that moss-caulking repairs occasionally took place, where only a short portion of the seam was renewed (Bonnamour 1981). It is plausible that on these occasions less carefully chosen material was used or even material from a different provenance.

Except for these four boats, the composition of moss caulking reported in Table 1 remained stable from the 12th to the 20th century, when N. crispa and A. viticulosus remained clearly dominant in all samples. In Lyons, Roman and Gallo-Roman boats have been found built with a different caulking technique using animal hair and pitch (Guyon et al. 2005; Guyon and Rieth 2009), but from the Middle Ages until the 20th century the Celtic technique of moss-caulking persisted. Moss-caulking was also used in the Netherlands at least since the Middle Ages and it persisted there until modern times (Cappers et al. 2000). In contrast to the Lyons area, in the Netherlands a major change took place after the 14th century with a switch from large pleurocarpous mosses from forest environments (notably with $N$. crispa) to Sphagnum and large pleurocarps from swampy habitats (mainly different Drepanocladus species). It is not clear, however, whether this switch was due either to local disappearance of $N$. crispa and other forest pleurocarps, or to a technological choice. However, swamp mosses are much harder to collect they lie low on the ground, are wet and consequently much heavier; they need drying before transport and usage and they are often intermingled with herbaceous plants. We are not aware of any technical advantage that may counterbalance these drawbacks. We agree therefore with Cappers et al. (2000) that the regression of large forest pleurocarpous bryophytes as caulking material by the 16th century in the Netherlands could be due to the disappearance of suitable forests.

Bryophyte communities have evolved through the centuries (Frahm and Wiethold 2004), and thus the habitats where we performed our experimental collections might have been different or formerly rarer. For instance, forest structure in the 18th century and the beginning of the 19th is usually described as much more open than today. Such conditions would be favourable to A. viticulosus, less sciaphilous and hygroclinous than $N$. crispa. Moreover, during the period from the 16th to the 19th century, cultivated land, and in general land use by man, reached its maximum and forests were generally overexploited. Habitats with large standing moss biomasses were less common than now, especially in lowland areas.

Cappers et al. (2000) hypothesized for the observed switch in the 14th century from forest pleurocarps $(N$. crispa being frequent) to swamp mosses that it was a result of this evolution of forest cover. After the 16th century the Netherlands probably even imported moss material for caulking from Belgium (Glime 2007; De Zuttere 2003). Today $N$. crispa is still a very rare bryophyte in the Netherlands (Kuijper 2000; Van der Ham et al. 2008). In contrast to most of western Europe, in our area $N$. crispa remained common throughout historical times (Hillier 1954; Touton 1962 1966), probably because of local topography and limestone predominance. This allowed the persistence of the use of $N$. crispa as caulking material.

How was the caulking moss selected?

To discuss the evolution of the usage of bryophytes for caulking it is essential to know how the raw material was collected. It is particularly interesting to know whether caulking-moss was collected from soil, tree bases or from rocks. The studies cited above mostly report moss communities typical of soil and rocky ground. The archaeological assemblages studied here (Table 1) most probably originated from tree trunks. About half of the records are very close in terms of composition to experimental gatherings from bark but dissimilar to collections from rocks (Fig. 3). Of course, the dominant species, A. viticulosus and $N$. crispa, grow on both bark and rocks. However, during our trials whenever we collected these two species from rocks, they were mixed with a significant part of Ctenidium molluscum (Table 2), a species with which it is 
not associated in Table 1. Gatherings in ancient times for these species are thus not likely to originate from rocks.

Another intriguing point in this context is that liverworts are totally absent from archaeological caulking material, while they are regularly present in samples from bark in Table 2 (e.g. Metzgeria furcata and Radula complanata). The lack of liverworts in caulking has already be noted by Cappers et al. (2000) and Bailly (1992 and unpublished reports). This lack could be due to preservation bias, liverworts being generally much more fragile than mosses. The low representation of liverworts in archaeological samples of diverse nature has already been reported and commented on by several authors (Dickson 1973; Frahm and Wiethold 2004). Therefore, this absence does not really bring into question the bark origin for caulking material studied here.

\section{Was Neckera crispa specifically targeted?}

Two moss species, $N$. crispa and A. viticulosus were particularly commonly used, and this in almost pure samples (Table 1). This raises the question whether they were specifically recognized and selected as such. $N$. crispa is quite frequently recorded in archaeological macro-remains (Grosse-Brauckmann 1979), its usage including boat caulking (Arnold 1977), house insulation (Pétrequin et al. 1991; Bailly personal communication), sole fabrication (Hochuli 2002), degreasing of pottery (Constantin and Kuijper 2002), food wrapping (Dickson 2000; Dickson et al. 2009) or for hygienic needs (Rybniček et al. 1998; Vadam 2003). Since archaeological records contain often pure $N$. crispa samples, the question of a selective collection of $N$. crispa has been discussed on several occasions (Rösch 1988; Rybniček et al. 1998 and references therein; Kuijper 2000). On average, in Table 2, N. crispa forms $61 \%$ of the biomass collected randomly from trunks with the criterion of something long, flexible and clean.

If, for example, $N$. crispa accounted only for a third or less of such randomly collected moss, it would support the hypothesis of a deliberate choice during collection of the moss used for observed caulk samples dominated by this species (Table 1). This is not the case, and leaves us with no sure indication that the collection of caulking moss specifically targeted a particular species.

The general characteristics needed for caulking, and effort for collection, alone can sufficiently explain the observations in Table 1. We may close this discussion with indications from a description of the making of a "sapine" (a common boat type for the area), established in 1849 for the Côte d'Or department (in Bonnamour 1986). Although this description gives detailed indications of what specific types of wood were to be used for the different parts of the boat, it indicates only "selected and well prepared moss" for caulking. If the idea of selection is clear, which underlines the importance of the caulking process, no name of a moss is given, not even a vernacular one like "boxmoss" or "oak-moss". Both are popular names for mosses that were frequently mentioned in interviews of former boat builders around 1980 (Bonnamour 1981), probably referring rather to a type of bryological community rather than to a particular species.

\section{Conclusions}

The local topography of the Rhône river area upstream of Lyons includes numerous well-marked elevations that remained forested even during the maximum extension of agricultural areas in the mid-19th century. Moss supply for boat caulking as well as $0^{+}$her uses has probably never been a problem there. The resource situation is quite different for the Saône River as this area was much more populated and cultivated. Analyses of caulking moss for the wrecks of Saint-Marcel and Ouroux-sur-Saône (13th and 18th century respectively) revealed almost exclusively A. viticulosus. This composition fits well with the environment of the limestone hills west of the river as a local source. Because of low topography and heavy pressure of human activities in this area, it is likely that local caulking moss was also supplied, at least during the 19th and 20th centuries, by moss material from the Jura Mountains. This is also supported by data from the literature (Bonnamour 1981; Janod 1983), and the fact that some boat builders from the Saône River travelled to the Jura Mountains to collect mosses (see description of Tony Huot above).

Thanks to the supply from the Jura Mountains, moss caulking survived in the Upper French Rhône and Saône River until recently with no major switch in species used at the end of the Middle Ages, contrary to what is documented elsewhere in Western Europe. The techniques and material that were used still resembled those used by Celtic boat builders.

Even though specific composition of caulking material usually showed one or two dominant species, species-targeted collecting is not probable. Rather, particular shapes, mechanical properties, cleanliness and sizes were targeted.

Our study demonstrates that in an area with no shortage of large forest pleurocarps for moss caulking of boats, the composition of caulk did not vary much from the Middle Ages to the Present. Thus our study reinforces the idea that the switch to swamp pleurocarps observed elsewhere in Western Europe was driven by the depletion of the populations of such forest mosses. In turn this depletion was probably induced by environmental changes due to deforestation. 
Acknowledgments We are very grateful to Gilles Bailly (Conser vatoire Botanique de Franche Comté) for help and discussions about the study of archaeological moss remains. We thank Véronique Blanchet Rossi (Archives municipales de St. Claude, Jura), Pierre Boudier (Muséum des sciences naturelles et de préhistoire de Char tres), René Cappers (Rijksuniversiteit Groningen), Stephan Hochuli (Section cantonale d'Archéologie de Zug, Suisse), André Julliard (CNRS), Fabrice Laurent and Alain Lavocat (Groupe de Recherche d'Archéologie Aquatique Lyonnais), Thierry Mahévas (Conservatoire et Jardins Botaniques de Nancy), Henri Plasson (Association Ensemble à Villerest), René Schumacker (Université de Liège, Bel gique) and Patrick Unterstock (calfat à Muttersholz, Haut Rhin) for their comments and help with many aspects. Furthermore, we grate fully acknowledge James H. Dickson, who provided helpful com ments on a previous version of the manuscript. We were very glad of the precious recollections of Odette Josserand concerning the caulk ing practices of her father (1902 1973), who was probably the last person to do this in the Saône area. Louis René Catcel's vivid descriptions of his practice of moss collecting and moss caulking 50 years ago were also much appreciated. We gratefully acknowledge the constructive comments of two anonymous reviewers and Frauke Behrendt (Brighton) for English language edition.

\section{References}

Argant J, Bailly G, Guyon M, Philippe M (2000) Un usage oublié de la mousse: le calfatage de bateaux. La Garance voyageuse 49:6 9

Arnold B (1975) The Gallo Roman boat from the Bay of Bevaix, Lake Neuchâtel, Switzerland. Int J Naut Archaeol 4:123 141

Arnold B (1977) Some remarks on caulking in Celtic boat construc tion and its evolution in areas lying northwest of the Alpine arc. Int J Naut Archaeol 6:293 297

Arnold B (1992) Batellerie gallo romaine sur le lac de Neuchâtel, 2 tomes. (Archéologie neuchâteloise, 12 et 13). Éditions du Ruau, Saint Blaise

Arnold B (2001) Quelques réflexions à propos d'un projet d'archéol ogie expérimentale: la construction d'Altaripa, réplique d'un chaland gallo romain découvert à Bevaix (NE). Zeitschrift für schweizerische Archäologie und Kunstgeschichte 58:41 46

Bailly G (1992) Epaves de la Saône: les bryophytes de calfatage. Unpublished Report

Bailly G (1997) Détermination des mousses de Chalain 3. In: Pétrequin P (ed) Les sites néolithiques de Clairvaux les lacs et Chalain (Jura). III Chalain station 3, 32002900 av. J. C, vol 1. Editions de la Maison des sciences de l'Homme, Paris, pp 77282

Blanc M (1986) Yon devient Artemare. Private edition

Bonnamour L (1981) La Saône une rivière des hommes. Editions Bonneton, Paris

Bonnamour L (1986) Bateaux de Saône. Mariniers d'hier et d'aujourd'hui. Société d'histoire et d'archéologie de Chalon, sur Saône

Bonnamour L (2000) Archéologie de la Saône, 150 ans de recherches. Paris

Cappers RTJ, Mook Kamps E, Bottema S, Van Zanten BO, Vlierman K (2000) The analysis of caulking material in the study of shipbuilding technology. Palaeohistoria 39/40:577 590

Clark P (2004) The Dover Bronze Age Boat. English Heritage, London

Constantin C, Kuijper WJ (2002) Utilisation de mousse comme dégraissant dans des céramiques néolithiques de France et de Belgique. Bulletin de la Société préhistorique française 99: 775783
De Zuttere P (2003) Le commerce des «mousses d'Ardennes» du $\mathrm{XVI}^{\circ}$ au $\mathrm{XX}^{\circ}$ siècle. Forêt Wallonne 62:12 18

Dickson JH (1973) Bryophytes of the Pleistocene. The British record and its chronological and ecological implications. Cambridge University Press, London

Dickson JH (2000) Bryology and the Iceman: chorology, ecology and ethnobotany of the mosses Neckera complanata Hedw. and Neckera crispa Hedw. In: Bortenschlager S, Oeggl K (eds) The Iceman and his natural environment. The man in the Ice, vol 4. Springer, Wien, pp 7788

Dickson JH, Hofbauer W, Porley R, Schmidl A, Kofler W, Oeggl K (2009) Six mosses from the Tyrolean Iceman's alimentary tract and their significance for his ethnobotany and the events of his last days. Veget Hist Archaeobot 18:13 22

Diekmann M (2003) Species indicator values as an important tool in applied plant ecology a review. Basic Appl Ecol 4:493 506

Dierssen K (2001) Distribution, ecological amplitude and phytoso ciological characterization of European bryophytes. Bryophyt Bibl 56:1 289

Diot M F (1991) Analyse palynologique des mousses de calfatage du bateau fluvial à Godefroy, commune de Bouliac (Gironde). In: Bizot B, Rieth E, Szepertyski B et al. (eds) Deux épaves d'époque moderne à Bouliac (Gironde). Aquitania 9:177 241

Ellenberg H, Weber HE, Düll R, Wirth V, Werner W, Paulissen D (1992) Zeigerwerte von Pflanzen in Mitteleuropa. Scr Geobot 18:1 258

Frahm J P, Wiethold J (2004) Die Moosflora des Mittelalters und der Frühen Neuzeit in Mitteleuropa nach archäologischen Funden zusammengestellt. Herzogia 17:303 324

Frey W, Frahm J P, Fischer E, Lobin W (2006) The liverworts mosses and ferns of Europe. Harley Books, Colchester

Glime J (2007) Bryophyte ecology. Michigan Technological Univer sity et l'International Association of Bryologists, http://www.bryoecol.mtu.edu/. 4 April 2011

Grave L (1857) Catalogue des plantes observées dans l'étendue du département de l'Oise. A. Desjardins, Beauvais

Grosse Brauckmann G (1979) Major plant remains of moor profiles from the area of a stone age lakeshore settlement on Lake Duemmer, West Germany. Phytocoenologia 6:106 117

Guyon M, Rieth E (2009) The Gallo Roman wrecks from Lyon Parc Saint Georges (France): new archaeological data on ancient inland «bottom based» shipbuilding. In: Bockius R (ed) Between the seas/transfer and exchange in nautical technology: proceed ings of the 11th international symposium on boat and ship archaeology, Mainz 2006. Römisch Germanisches Zentralmuse um Mainz, pp 157159

Guyon M, Laurent F, Rieth E (2005) Histoire d'un bord de Saône, tome IV: Les bateaux de Saint Georges. Batelleries gallo romaine, médiévale et moderne. In: Ayala G (ed) Lyon (Rhône) La fouille du Parc Saint Georges, place Benoît Crépu. Rapport final d'opération, Lyon

Heiss AG, Reitmaier T (2005) Zur Abdichtung der Plankennähte am Beispiel von drei neuzeitlichen Schiffswracks aus der Schweiz. Nachrichtenblatt Arbeitkreis Unterwasserarchäologie 11/12: 3336

Heras Pérez P, Infante Sánchez M, Izaguirre Lacoste M (2009) On the use of mosses in the building of a XVth. century ship in Northern Spain. Cryptogam Bryol 30:177 184

Hill MO, Bell N, Bruggemen Nannenga MA, Brugues M, Cano MJ, Enroth J, Flatberg KI, Frahm J P, Gallego MT, Garilleti R, Guerra J, Hedenäs L, Holyoak DT, Hyvönen J, Ignatov MS, Lara F, Mazimpaka V, Munoz J, Söderström L (2006) An annotated checklist of the mosses of Europe and Macaronesia. J Bryol 28:198 267

Hillier L (1954) Catalogue des Mousses du Jura. Annales Scientif iques de l'Université de Besançon, $2^{\circ}$ série (botanique) 3 
Hochuli S (2002) Teil eines neolithischen Schuhs aus Zug. Jb Schweiz Ges Ur Frühgesch 85:45 54

Janod R (1983) Les radeliers de la vallée de la Bienne. Bulletin Les Amis du vieux Saint Claude 6:12 25

Knörzer K H (1999) Kalfatern vom Neolithikum bis zum Mittelalter. In: Rolle R, Andraschko F M (eds) Frühe Nutzung pflanzlicher Ressourcen. LIT Verlag, Berlin, pp 8387

Kuijper WJ (2000) The former occurrence of Neckera crispa Hedw. in the Netherlands. Lindbergia 25:28 32

Legendre P, Legendre L (1998) Numerical ecology. Elsevier, Amsterdam

Ochsner F (1975) Neckera crispa Hedw. an Pfahlbau Fundstellen in der Schweiz. Phytocoenologia 2:9 12

Pétrequin P, Pétrequin A M, Monnier J L, Richard A, Gentizon A L (1991) Construire une maison 3000 ans avant J. C. Errance, Paris

Philippe M (2006) La liste des Bryophytes et apparentées de l'Ain de Jean Baptiste Touton (1962 1966) revisitée. Nouvelles Archives de la Flore jurassienne 4:109 118

Rieth E (1996) Le calfatage des barges et des galées au Clos des Galées de Rouen (1293 1418). In: Ciciliot F (ed) Navalia Archeologia e Storia. The international Propeller Club Port of Savona, Savone

Rieth E (2010) Les épaves de Saint Georges Lyon (Ier XVIIIe siècles): analyse architecturale et études complémentaires. Archaeonautica 16:1 335

Rochigneux M (1891) Les pics basaltiques du Forez, leurs antiquités et leurs traditions. La Diana 16:24 28
Rösch M (1988) Subfossile Moosfunde aus prähistorischen Feu chtbodensiedlungen: Aussagemöglichkeiten zu Umwelt und Wirtschaft. In: Küster H (ed) Der prähistorische Mensch und seine Umwelt. Theiss, Stuttgart, pp 177198

Rybniček K, Dickson JH, Rybničekova E (1998) Flora and vegetation at about A.D. 1100 in the vicinity of Brno, Czech Republik. Veget Hist Archaeobot 7:155 165

Stapper NJ, Franzen Reuter I (2010) Looking back on 15 years of research on bioindication with Jan Peter Frahm in Bonn. Trop Bryol 31:1 4

Touton JB (1962 1966) Les muscinées du département de l'Ain. Bulletin mensuel Société Linnéenne Lyon 33 (1962): 46 63, 33 (1964): 117 122, 35 (1966): 266279

Vadam J C (2003) Les bryophytes observées dans les fouilles de latrines du XVI siécle à Montbéliard. Bulletin de la société d'histoire naturelle du pays de Montbéliard 2003:145 152

Van der Ham RWJM, Kuijper WJ, Kortselius MJH, van der Burgh J, Stone GH, Brewer JG (2008) Plant remains from the Kreftenheye Formation (Eemian) at Raalte, The Netherlands. Veget Hist Archaeobot 17:127 144

Wright EV (1994) The North Ferriby boats a final report. In: Westerdahl C (ed) Crossroads in ancient shipbuilding. Oxbow Monogr 40:29 34 